\title{
MADDİ DURAN VARLIKLARIN RAPORLANMASINDA GERÇEĞE UYGUN DEĞER HIYERARŞISIININ KULLANILMASI
}

Yrd.Doç.Dr. Erkan ÖZTÜRK*

\section{$\ddot{O Z Z}$}

Bu çalı̧̧mada, Vergi Usul Kanunu (VUK) uyarınca öngörülen amortisman yöntemlerine yönelik uygulamalar ile "TMS 16 Maddi Duran Varliklar” standardı uyarınca öngörülen amortisman yöntemlerine yönelik uygulamalar karşılaştırılarak, yeni yaklaşımların uygulanabilirliği sorgulanmak istenmiştir. Buna bağlı olarak, kalıntı değerin tahmin edilerek amortisman hesaplamasına katılması ve “TMS 8 Muhasebe Politikalarl, Muhasebe Tahminlerinde Değişiklikler ve Hatalar” standardı uyarınca bir iktisadi kıymetin aktife girdiği tarih itibariyle tahmin edilen kalıntı değerinin yararlı ömür süresi içerisinde değişmesi, gerçeğe uygun değer hiyerarşisi göz önünde bulundurularak hem maliyet modeline göre hem de yeniden değerleme modeline göre örneklendirilmiştir. Böylelikle, amortisman yöntemlerinin Türkiye Muhasebe/Finansal Raporlama standartları çerçevesinde nasıl uygulanabileceğine yönelik öneriler sunulmuştur.

Anahtar Sözcükler: Maddi Duran Varlıklar, Kalıntı Değer, Gerçeğe Uygun Değer.

Jel Sinıflandırmast: $M 40$, M41

\section{USING THE FAIR VALUE HIERARCHY ON REPORTING OF TANGIBLE ASSETS}

\begin{abstract}
In this study, applicability of new approaches has been questioned by comparing applications of depreciation methods of Tax Procedure Law (TPL) and "TAS 16 Tangible Fixed Assets". Accordingly, depreciation calculation by estimating residual value and change of this value that estimated on date of entry assets of a depreciation unit in useful life in accordance with "TAS 8 Accounting Policies, Changes in Accounting Estimates and Errors" are exemplified both according to cost and revaluation models by taking into fair value hierarchy. Thus, recommendations of how to apply depreciation methods with Turkish Accounting/Financial Reporting Standards framework are presented.
\end{abstract}

Keywords: Tangible Assets, Residual Value, Fair Value.

Jel Classification: M40, M41

\footnotetext{
*Kırklareli Üniversitesi, İktisadi ve İdari Bilimler Fakültesi, İşletme Bölümü, erkan.ozturk@klu.edu.tr
} 


\section{GİRIŞ}

Uluslararası nitelikteki şirket sayısının giderek artması ve özellikle ekonomik alanda sınırların genişlemesi ile birlikte sosyal ve ekonomik alanlardaki ilişkiler uluslararası boyutta değerlendirilmeye başlanmıştır. Bu dönüşümün bir sonucu olarak, sermaye piyasalarının önemi gün geçtikçe daha fazla artmış ve dolayısıyla muhasebede ortak dil oluşturulması ihtiyacı daha fazla önem kazanmıştır. Bu kapsamda, muhasebeye uluslararası düzeyde yön veren kuruluşlar konuyla ilgili birçok çalışmalar yapmışlardır.

Finansal bilgi amaçlı raporların birbirleriyle uyumlu hale getirilebilmesi amacıyla, Uluslararas1 Muhasebe Standartları Kurulu (IASB) tarafindan, Uluslararas1 Muhasebe Standartlarını (IAS) ve Uluslararası Finansal Raporlama Standartları (IFRS) oluşturulmuştur. Türkiye'de ise, uluslararası muhasebe standartları ile uyumlaştırma çalışmalarının 1990'lara dayanmasına rağmen, konuya yönelik çalışmalar 1994'te Türkiye Muhasebe ve Denetim Standartları Kurulu'nun (TMUDESK) ve 1999'da Türkiye Muhasebe Standartları Kurulu'nun (TMSK) kurulmasiyla resmiyet kazanmıştır. TMSK, IAS ve IFRS'yi Türkiye Muhasebe Standartları (TMS) ve Türkiye Finansal Raporlama Standartları (TFRS) adı ile tercüme ederek muhasebe uygulayıcılarının yorum ve görüşlerine sunmuştur.

Türkiye Finansal Raporlama Standartlarının kavramsal çerçevesi incelendiğinde, sermaye sahiplerinin bilgi beklentisine uygun finansal raporlar sunulabilmesi amaciyla tarihi maliyet esasına alternatif olarak gerçeğe uygun değer esasına dayalı bazı ölçüm yaklaşımlarına yer verildiği görülmektedir (Finansal Raporlamaya İlişkin Kavramsal Çerçeve, s. 20). Bu doğrultuda, raporlanacak finansal bilgilerin gerçeğe uygun değer hiyerarşisi göz önünde bulundurularak tespit edilmesi önem arz etmektedir.

Türkiye Finansal Raporlama Standartlarının birçok bölümünde geçmekte olan gerçeğe uygun değer kavramı, muhasebe uygulamalarından doğru finansal sonuçlar elde edilebilmesi açısından oldukça önemlidir. Bilimsel literatür incelendiğinde, gerçeğe uygun değer kavramının ve uygulama hiyerarşisinin birçok çalışma içerisinde farklı yönleri ile ele alındığı görülmektedir. Ancak, maddi duran varlıklar ile ilgili yapılmış çalışmaların birçoğunda; gerçeğe uygun değer, TMS 16 Maddi Duran Varlıklar standardı çerçevesinde sunulan açıklamalar sınırı içerisinde tartışılmıştır. Daha önce yapılımış olan çalışmalardan farklı olarak bu çalışmada; maddi duran varlıkların gerçeğe uygun değer tespiti için, TMS 16 Maddi Duran Varlıklar ve TMS 8 Muhasebe Politikaları, Muhasebe Tahminlerinde Değişiklikler ve Hatalar standartlarının müşterek etkilerini göz önünde bulunduran çeşitli uygulamalara yer verilmiştir.

Yapılan bu çalışmada; ilk olarak, Türk Vergi Usul Kanunu ve Türkiye Muhasebe Standartlarınca öngörülen amortisman hesaplama yaklaşımları karşılaştırılmıştır. Ardından, gerçeğe uygun değer hiyerarşisine dayalı ölçüm esaslarının amortisman yaklaşımları üzerindeki etkileri de göz 
önünde bulundurularak elde edilecek itfa değerlerinin finansal tablolar üzerindeki etkilerine ilişkin çeşitli değerlendirmeler sunulmuştur.

\section{AMORTISMANA TABİ DEĞERIN SAPTANMASI VE AMORTISMAN YÖNTEMLERININ INCELENMESI}

Amortisman ayrılacak varlığın piyasa değeri, zaman içerisinde enflasyon ve değer yitirme gibi sebeplerden ötürü defter değerinden farklılaşmaktadır (Demir ve Bahadır, 2007: 69). Defter değerinin gerçeğe uygun değer esasında piyasa değerine yaklaştırılması ile amortisman hesaplaması daha sağlıklı bir biçimde yapılabilmektedir. Amortismana tabi değerin saptandığı bu süreçte, Vergi Usul Kanunu ile Türkiye Muhasebe Standartları farklı tespitlerde bulunmaktadır.

$\mathrm{Bu}$ bölümde, amortismana tabi değerin tespitinin nasıl yapılacağı değerlendirilecek, söz konusu tanımlamalar ve yöntemler incelenecektir. Böylelikle, konu ile ilgili kavramsal çerçeve oluşturulacaktır.

\subsection{Amortisman Kavramı}

Amortisman, bir duran varlığın aşınması, yıpranması, eskimesi veya modasının geçmesi durumları dikkate alınarak belirlenecek faydalı ömrü içerisinde gidere dönüştürülmesi işlemidir (Lazol, 2004: 156, Gençoğlu, 2010: 260).

Birden fazla muhasebe döneminde kullanılması beklenen, sınırlı bir hizmet süresi olan, bir işletme tarafından mal ve hizmet üretim ve tedarikinde, işletme içi genel yönetim amaçları için edinilen varlıklar amortismana tabidir. Söz konusu varlıklar kullanıldıkları süre içinde yıpranma, aşınma ve işletme fonksiyonlarına katkı verme gücünü yitirme olgusu ile karşı karşıyadır. Bu durum işletmenin katlandığı bir maliyeti ifade eder ve bu maliyet unsuru "amortisman" olarak nitelenir (Sevilengül, 2011: 410).

Amortisman kavramının varlık nedeni dört temel esasa bağlanmaktadır (Sevilengül, 2005: 422). Sevilengül'e göre amortisman kavramı;

- Değerleme,

- Tüketim,

- Yenileme ve

- Dağıtım,

yaklaşımları ile açıklanmaktadır.

Tablo 1. Amortismanın Oluşum Nedenleri

\begin{tabular}{|l|l|}
\hline Amortisman Yaklaşımları & Amortismanın Amacı \\
\hline Değerleme Yaklaşımı & Aktifin düzeltilmesi \\
\hline Tüketim Yaklaşımı & Faydanın tüketilmesi \\
\hline Yenileme Yaklaşımı & Sermayenin korunması \\
\hline Dağıtım Yaklaşımı & Maliyetlerin dönemlere dağıtılması \\
\hline
\end{tabular}


Amortisman yaklaşımları, amortismanın varlık nedenini farklı açılardan ele almaktadır. Değerleme yaklaşımına göre amortisman, duran varlığın aktif içerisindeki gerçek değerini belirlemeye yarayan bir araçtır. Tüketim yaklaşımına göre amortisman, duran varlıklardan elde edilen faydanın tüketilmesi anlamına gelmektedir. Yenileme yaklaşımına göre amortisman, duran varlığın yenilenmesi için fon biriktirilmesi anlamı taşımaktadır. Dağıtım yaklaşımına göre ise amortisman, duran varlığın kalıntı değeri düşüldükten sonra kalan değerinin faydalı olduğu süreye dağıtılmasıdır.

$\mathrm{Bu}$ yaklaşımlar 1şığı altında amortisman ayırmanın amacının, duran varlıkların maliyetlerini sistemli olarak kullanıldıkları süreye dağıtmak ve her yıl payını gider kaydetmek suretiyle, kullanım süresi sonunda kullanılamaz hale geldiği varsayılan duran varlığın yenilenmesi için fon yaratmak olduğu söylenebilir (Gençoğlu, 2013: 391).

\section{2. İktisadi Kıymetin Amortismana Tabi Değerinin Tespiti}

Finansal bilgi kullanıcılarının ihtiyaç duydukları bilgi düzeyi hem güvenilir, hem de yatırım ve yönetim kararlarında etkili olabilecek yeterlilikte olmalıdır (Tokay ve Deran, 2008: 17). Tarihi maliyet esasına dayalı olarak yapılan değerlemeler finansal bilgi kullanıcıları için güvenilir bilgi sunmaktadır; ancak bu bilgi, karar verme aşamasında bazen yararlı bilgi sağlayamamaktadır. Bu sebeple, bir iktisadi kıymetin amortismana tabi değerinin tespit edilebilmesi için, öncelikli olarak değerinin gerçeğe uygun bir biçimde saptanabilmesi ve sonraki aşamada ise, amortisman kapsamının ve yönteminin belirlenmesi gerekmektedir.

\subsection{1. İktisadi Kıymetin Gerçeğe Uygun Değerinin Saptanması}

Varlık olarak muhasebeleştirme koşullarını sağlayan bir iktisadi kıymet maliyet esası kavramı gereğince işletmenin aktifine maliyet bedeli ile kaydedilmektedir. Ancak zaman içerisinde, tarihi maliyet esasına göre yapılan kaydın değeri ile cari değer arasında fark ortaya çıkmaktadır. Ayrıca, varlığın kullanımındaki değişiklikler, beklenmedik aşınma ve yıpranmalar ve teknolojik gelişmeler varlığın değeri ve kullanım ömrü üzerinde etkili olmaktadır. Böyle bir durumda; kayıtlı değerin, zamanın şartlarına uygun ve söz konusu varlığın kalan kullanım ömrü ile orantılı bir büyüklükte izlenmesi gerekmektedir.

Vergi Usul Kanunu'nun 269-271. Maddeleri göz önünde bulundurulduğunda, amortismana tabi iktisadi kıymetlerin işletme aktifine girdikten sonraki süreçte maliyet modeli ile değerlendiği anlaşılmaktadır (Ayçiçek, 2011: 126). Maliyet modeli, bir iktisadi kıymetin, varlık olarak ilk muhasebeleştirmeden sonra finansal tablolarda maliyetinden birikmiş amortisman ve varsa birikmiş değer düşüklükleri düşüldükten sonra kalan değeri ile gösterilmesini ifade etmektedir.

TMS 16 Maddi Duran Varlıklar standardı, muhasebeleştirme sonrası değerinde değişiklik meydana gelen bir varlığın gerçeğe uygun değerinin güvenilir bir biçimde ölçülebiliyor olması halinde yeniden değerleme modelinin kullanılmasını önermektedir. Yeniden değerlenmiş tutar, yeniden değerleme tarihindeki gerçeğe uygun değerinden, müteakip birikmiş amortisman ve müteakip birikmiş 
değer düşüklügü zararlarının indirilmesi suretiyle bulunan değerdir (TMS-16: Maddi Duran Varlıklar Standard1, Md. 31).

Yeniden değerleme modeli gerçeğe uygun değer esası ile birlikte uygulanabilmektedir (Yükçü ve İçerli, 2007: 19). Bu sebeple, yeniden değerleme modelinin gerçeğe uygun değer hiyerarşisi ile uyumlu olarak icra edilmesi ve amortismana tabi değerin cari değer üzerinden değerlendirilmesi gerekmektedir. Gerçeğe uygun değer hiyerarşisi gereğince yapılacak değerlemede öncelik, yeniden değerlenecek varlıkların aktif piyasalardaki kotasyon fiyatlarında olacaktır. Ancak bazı durumlarda bu fiyat bilgisi yeniden değerleme için yararlı bilgi sağlayamamaktadır (TFRS-13: Gerçeğe Uygun Değer Ölçümü, s. 13). Bu gibi durumlarda, yeniden değerlenecek varlıklara benzer türdeki varlıkların aktif piyasalardaki kotasyon fiyatları baz alınabilmektedir. Yeniden değerlenecek varlık için fiyat bilgisi sunan aktif bir piyasanın bulunmaması halinde ise, piyasa yaklaşımı, gelir yaklaşımı veya maliyet yaklaşımı ölçüsünde uygulanacak bir değerleme yaklaşımı yardımı ile gerçeğe uygun değer ölçümü yapılmalıdır (Pamukçu, 2011: 87). Bunlarla birlikte, gerçeğe uygun değer tespit edilirken, uygulanacak yaklaşımın makul seviyede desteklenebilir olması önem arz etmektedir.

Yeniden değerleme yapılması halinde; o tarihteki birikmiş amortisman tutarı, yeniden değerlemesi yapılan varlı̆̆ın brüt defter değerinde yapılacak değişiklik ile orantılı olarak değiştirilmektedir. Böylelikle, yeniden değerleme sonrasındaki varlığın defter değeri yeniden değerlenmiş tutarına eşit olmaktadır.

\subsubsection{Amortismana Tabi Değerin Gerçeğe Uygun Değer Hiyerarşisine Göre Belirlenmesi}

Vergi Usul Kanunu'nun 313. Maddesi uyarınca; işletmede bir yıldan daha uzun süre kullanılması planlanan ve yıpranmaya, aşınmaya veya kıymetten düşmeye maruz kalan gayrimenkullerle, gayrimenkul gibi değerlenen iktisadi kıymetlerin; alet, edevat, mefruşat, demirbaş ve sinema filmlerinin değerlemeye ilişkin kanunlar çerçevesinde tespit edilen değerleri amortisman işlemine tabidir.

TMS 16, amortismana tabi değerin belirlenmesi konusunda Vergi Usul Kanunu mevzuatına göre oldukça önemli bazı değişiklikler getirmektedir. Bu değişikliklerden en önemlisi, amortismana tabi iktisadi kıymetin amortismana tabi değerinin hesaplanmasında kalıntı (hurda) değerinin ${ }^{1}$ önemsiz kabul edilecek bir tutar olmaması durumunda maliyet bedelinden düşülmesidir (Şen, 2011: 138). Ancak kalıntı değerinin olmaması veya önemsiz olması durumunda, bu değerin dikkate alınması zorunlu olmaktan çıkar. Hesaplamada, paranın zaman itibariyle değerinde dikkate alınması gereklidir.

TMS 16, Madde 6'ya göre amortisman, bir varlığın amortismana tabi tutarının yararlı ömür süresince sistematik olarak dağıtılmasını ifade etmektedir. VUK kalıntı değerini önemsiz olarak kabul ederken, TMS 16 kalıntı değerinin doğru tespiti ve hesaplamalarda kullanılmasını önemini vurgulamaktadır. Varlığın kalıntı değeri defter değerini aşmadığı sürece, gerçeğe uygun değerinin

\footnotetext{
${ }^{1}$ Kalıntı değeri, varlı̆̆ın faydalı ömrü sonunda elden çıkartılması sonucunda elde edilecek tutardan, elden çıarma maliyetlerinin düşülmesi suretiyle hesaplanır.
} 
defter değerini aştı̆̆ durumlarda dahi amortisman gideri finansal tablolara yansıtılır. Varlığın kalıntı değeri varlığın defter değerine eşit ya da daha fazla bir tutara yükseldiği durumda da amortisman ayırma işlemi durdurulur.

Kalıntı değer belirlenirken, makul seviyede tahmin yapılması ve bu tahminin düzenli olarak gözden geçirilmesi gereklidir (Finansal Raporlamaya İlişkin Kavramsal Çerçeve, s. 18). Kalıntı değerdeki değişiklikler bir tahmin niteliğinde olduğundan, TMS 8 hükümlerine göre muhasebeleştirilmektedir. (Örten vd., 2010: 201). Ancak, kalıntı değerin gerçeğe uygunluğu konusundaki güvensizlik, amortismana tabi iktisadi kıymetlerin amortismana tabi değerlerine olan güven düzeyini de azalmaktadır. Bu duruda, yapılacak amortisman hesaplamaları ve nihayetinde yapılacak kayıtların geçerliliği ile ilgili kuvvetli şüphe meydana gelmektedir. Bu şüphenin en aza indirilebilmesi için, amortismana tabi değerin gerçeğe uygun değer hiyerarşisine göre belirlenmesi, uygun bir çözüm önerisi olarak düşünülmektedir.

Gerçeğe uygun değer hiyerarşisine göre bir varlığın veya yükümlülüğün değeri, güvenilir olarak ölçülebilen piyasa fiyatı, emsal olarak ölçülebilen piyasa fiyatı veya bunların bulunmaması durumunda seçilebilecek uygun değerleme tekniğiyle belirlenecek bir büyüklüğü ifade etmektedir (TFRS-13, Gerçeğe Uygun Değer Ölçümü: s. 13). Buna göre, kalıntı değer tahminlerinin, gerçeğe en uygun değer hiyerarşisi içerisinde yapılması gerekmektedir.

\subsection{Amortisman Yöntemlerinin İncelenmesi}

Muhasebe literatüründe adı geçen ve farklı şekillerde uygulanan çeşitli amortisman yöntemleri bulunmaktadır. Genel kabul görmüş yaklaşıma göre amortisman yöntemi uygulaması, amortismana tabi varlıkların maliyetinin dönemlere dağıtılması işlemidir. Buna göre, seçilen amortisman yöntemi, o yılın amortisman gideri tutarı üzerinde belirleyici olacaktır. (Süer ve Şenyiğit, 2006: 209).

\subsubsection{Vergi Usul Kanunu Açısından Amortisman Yöntemleri}

Amortisman işlemlerine ilişkin temel konular ve amortisman ayırma yöntemleri Vergi Usul Kanunu'nun 313-321. Maddeleri arasında ele alınmıştır. Vergi Usul Kanunu'na göre; normal amortisman yöntemi, azalan bakiyeler yöntemi (hızlandırılmış yöntem) ve fevkalade amortisman yöntemi (olağanüstü amortisman yöntemi) olmak üzere üç amortisman yöntemi uygulanmaktadır. Azalan bakiyeler yönteminde, amortisman oranı \% 50'yi aşmamak koşuluyla normal usule göre belirlenen oranın iki katı uygulanmaktadır. Fevkalade amortisman yöntemi ise, tamamen VUK' un 317'nci Maddesi'nde belirtilen özel koşulların ortaya çıkması halinde uygulanabilecek, arızi bir yöntemdir (İpekoğlu ve Tekşan, 2008: 46).

Mükellefler "normal" ve "azalan bakiyeler" usullerinden birini "iktisadi ve teknik bakımdan bütünlük teşkil etmek" koşuluyla, diledikleri gibi seçebilmektedirler. VUK'un 320 Maddesi’ne göre normal usul seçilirse bir usulden bir daha dönülemez iken, keyfiyeti beyannamelerde ve bilançolarda belirtilmek koşuluyla azalan bakiyeler usulünden, normal usule geçiş kabul edilmektedir. Ancak, bu geçişte de amortisman süresi değiştirilmemektedir. 
Normal Amortisman Yöntemi: VUK, Md. 315'e göre; Mükellefler amortismana tabi iktisadî kıymetlerini Maliye Bakanlığı'nın tespit ve ilan edeceği oranlar üzerinden itfa ederler. İlan edilecek oranların tespitinde iktisadî kıymetlerin faydalı ömürleri dikkate alınır.

Azalan Bakiyeler Yöntemi: VUK, Md. 315'e göre; bilanço esasına göre defter tutan mükelleflerden dileyenler, amortismana tabi iktisadi değerlerini, azalan bakiyeler üzerinden amortisman usulü ile yok edebilirler. Amortisman süresi normal amortisman nispetlerine göre hesaplanır. Bu sürenin son yılına devreden bakiye değer, o yıl tamamen yok edilir.

Fevkalade Amortisman Yöntemi: Mükellefler, usulüne göre tespit edilen nispetleri aşmamak şartıyla, amortismanları diledikleri nispetler üzerinden hesaplayabilirler; ancak, uygulamaya başladıkları amortisman nispetlerini izleyen faaliyet yıllarında değiştiremezler. Ancak, VUK Madde 317’ye göre; amortismana tabi varlığın, olağanüstü bir durum neticesinde, normalden fazla aşınma ve yıpranmaya maruz kalması durumunda, mükelleflerin müracaatları üzerine ve ilgili bakanlıkların mütalaası alınmak suretiyle, Maliye Bakanlığı'nca her işletme için işin mahiyetine göre ayrı ayrı belli edilen "fevkalade ekonomik ve teknik amortisman nispetleri" uygulanır.

VUK Madde 320'de, faaliyetleri kısmen veya tamamen binek otomobillerin kiralanması veya çeşitli şekillerde işletilmesi olanların bu amaçla kullandıkları binek otomobilleri hariç olmak üzere, işletmeye ait binek otomobillerin aktife girdiği hesap dönemi için ay kesri tam ay sayılmak suretiyle kalan ay süresi kadar amortisman ayrılması ve amortisman ayrılmayan süreye isabet eden bakiye değerin amortisman süresinin son yılında itfa edilmesi gerektiği belirtilmektedir. Kanunda yer alan bu sınırlı uygulama kıst amortisman olarak adlandırılmaktadır.

\subsubsection{Türkiye Muhasebe Standartları Açısından Amortisman Yöntemleri}

TMS 16 Maddi Duran Varlıklar Standardının amac1, maddi duran varlıkların (devamlı kulanım amaçlı) ve bunların amortismanlarının değerlemesi ve bunlarla ilgili olarak bilanço eklerinde verilmesi gereken en az bilgilerin belirlenmesidir (Örten vd., 2010: 207).

TMS 16 Maddi Duran Varlıklar Standardı uyarınca bir varlığın amortismana tabi tutarının yararlı ömrü boyunca ve sistemli bir biçimde dağıtımı için kullanılabilecek yöntemler; doğrusal (normal) amortisman yöntemi, azalan bakiyeler yöntemi ve üretim miktarı yöntemi olmak üzere üç tanedir. $\mathrm{Bu}$ yöntemlerden, doğrusal amortisman ve azalan bakiyeler yöntemleri VUK'un da yer almaktadır. TMS 16'da yer verilen üretim miktarı yöntemi ise; VUK içerisinde, madenler için ayrılması gereken amortisman tutarının hesaplanmasında kullanılmaktadır (Hatunoğlu ve Kı1lı, 2014: $61)$.

TMS 16, md. 75 'de amortisman yönteminin seçimi ve amortismana tabi varlıkların yararlı ömür tahminlerini belirlerken işletmelerin kendi tecrübelerine dayandırarak takdir edeceği belirtilmiştir.

Doğrusal Amortisman Yöntemi: Doğrusal amortisman yöntemi Türk Vergi Mevzuatında kabul edilen normal amortisman yöntemi ile aynı şekilde hesaplanıp aynı sonucu vermekle birlikte 
varlığın kalıntı değeri olduğu ve yıllara göre değiştiği durumlarda farklı sonuç vermektedir. Doğrusal amortisman yönteminde, varlığın kalıntı değeri değişmediği sürece, amortisman gideri Türk Vergi Mevzuatında kabul edilen normal amortisman yönteminde olduğu gibi yararlı ömrü boyunca sabittir.

Azalan Bakiyeler Yöntemi: Azalan bakiyeler yönteminde muhasebesi ve uygulaması Türk Vergi Mevzuatına benzer, fakat, standartta bu usulün uygulanması için azami ve asgari bir oran yoktur. Vergi mevzuatının aksine oran (yararlı ömür) belirlemek serbesttir. Yöntemde önemli olan, amortisman giderinin, yararlı ömür boyunca azalarak hesaplanmasıdır. (Akpınar, 2012: 230)

Üretim Miktarlarına Göre Amortisman Yöntemi: Varlığın çalışma yoğunluğu oran hesaplamada esas alınır. Üretim miktarı yönteminde beklenen kullanım ya da üretim miktarı üzerinden amortisman ayrılır. İşletme, varlığın gelecekteki ekonomik yararlarının beklenen tüketim biçimini en çok yansıtan yöntemi seçer. Seçilen yöntem gelecekteki ekonomik yararların beklenen tüketim biçiminde bir değişiklik olmadıkça dönemden döneme tutarlı olarak uygulanır.

VUK' da binek otomobiller için geçerli olan kıst amortisman uygulaması ile Türkiye Muhasebe/Finansal Raporlama Standartları'ndaki anlayış arasında da farklı1ık bulunmaktadır. VUK' daki uygulamada faaliyet ömrü yıl olarak ele alınmaktayken, standartlarda ay hesabı tam anlamıyla uygulanmaktadır. Daha açık bir ifadeyle; VUK'a göre ilk yılda hesaplanmayan amortisman tutarı son yılın amortisman tutarına ilave edilirken, standarda göre ilk yıldan kalan aylara ait hesaplanmayan amortisman tutarı, son tam yıldan sonraki yılın ilgili ayları için kayda alınır. Kıst amortisman uygulamasındaki anlayış farklılıkları işletmelerin faaliyet sonuçlarını etkilemektedir (Elitaş vd., 2009: 22).

\subsubsection{Amortisman Yöntemlerinin VUK ve TMS Açısından Karşılaş̧ırıılması}

Amortisman yöntemlerinin ve uygulanışlarının Vergi Usul Kanunu ve Türkiye Muhasebe Standartları kapsamında yapılan karşılaştırması aşağıdaki tabloda sunulmaktadır.

Tablo 2. Amortisman Yöntemlerinin VUK ve TMS Açısından Karşılaştırması

\begin{tabular}{|l|l|l|}
\hline & Vergi Usul Kanunu & Türkiye Muhasebe Standartları \\
\hline Amortismana Tabi Değer & Maliyet bedelidir. & $\begin{array}{l}\text { Maliyet bedelinden kalıntı değer } \\
\text { düşüldükten sonraki değerdir. }\end{array}$ \\
\hline Amortisman Ayırma Sınırı & $880 \mathrm{TL}^{2}$ 'dir. & Sınır belirtilmemiştir. \\
\hline $\begin{array}{l}\text { Amortismana Tabi } \\
\text { Kısımlar }\end{array}$ & Varlığın bütünüdür. & Varlığın kısımlarıdır. \\
\hline Amortisman Dönemi & $\begin{array}{l}\text { Varlığın aktife girdiği } \\
\text { dönem başlamaktadır. }\end{array}$ & $\begin{array}{l}\text { Varlık kullanılabilir olduğunda } \\
\text { başlamaktadır. }\end{array}$ \\
\hline Amortisman Süresi & $\begin{array}{l}\text { Maliye bakanlığınca } \\
\text { belirlenmektedir. }\end{array}$ & $\begin{array}{l}\text { İşletme tarafından belirlenecek yararlı } \\
\text { ömürdür. }\end{array}$ \\
\hline Amortisman Tutarı & $\begin{array}{l}\text { Maliyet bedeli ölçüsünde } \\
\text { sabittir. }\end{array}$ & $\begin{array}{l}\text { Kalıntı değer tahminindeki değişmeye } \\
\text { göre değişebilir. }\end{array}$ \\
\hline Amortisman Yöntemleri & $\begin{array}{l}\text { - Normal } \\
\text { - Azalan bakiyeler } \\
\text { - Olağanüstü }\end{array}$ & $\begin{array}{l}\text { - Doğrusal } \\
\text { - Azalan bakiyeler } \\
\text { - Üretim Miktarı }\end{array}$ \\
\hline
\end{tabular}

\footnotetext{
${ }^{2} 01.01 .2015$ tarihinden itibaren doğrudan gider yazma sınırı 880 TL'dir.
} 


\begin{tabular}{|c|c|c|}
\hline Amortismanı Durdurma & $\begin{array}{lcr}\text { Varlık satıldığında } & \text { veya } \\
\text { faydalı ömür } & \text { sona } \\
\text { erdiğinde } & \text { amortisman } \\
\text { ayırma işlemi durdurulur. }\end{array}$ & $\begin{array}{l}\text { Satış amaçlı duran varlıklar ve gelecekte } \\
\text { ekonomik yarar beklenmeyen duran } \\
\text { varlıklarda amortisman ayırma işlemi } \\
\text { durdurulur. }\end{array}$ \\
\hline $\begin{array}{l}\text { Kist Amortisman } \\
\text { Uygulaması }\end{array}$ & $\begin{array}{l}\text { Binek otomobillerde } \\
\text { uygulanmaktadır. } \\
\text { Illk y1lın hesaplanmayan } \\
\text { amortisman tutarı son y1la } \\
\text { ilave edilmektedir. }\end{array}$ & $\begin{array}{l}\text { Tüm duran varlıklara uygulanmaktadır. } \\
\text { İlk y1lın hesaplanmayan amortisman } \\
\text { tutarı son yı müteakip yılın ilgili } \\
\text { aylarında itfa edilmektedir. }\end{array}$ \\
\hline
\end{tabular}

Kaynak: Hatunoğlu ve Kıllı, 2014: 65’den uyarlanmıştır.

Türkiye Muhasebe Standartları, piyasa katılımcılarının ihtiyaçlarını en uygun şekilde karşılayacak güvenilir ve şeffaf finansal tabloların oluşturulması için finansal tablo kalemlerinin açıklanan değerleme ölçüleri kapsamında değerlendirilmesini öngörmektedir (Özkan ve Acar, 2010: 43).

TMS 16 gereğince, işletmenin, amortisman oran ve yöntemini kendi belirleme yetkisi esas olduğu için, başlangıçta belirlediği koşullarda, sonradan ortaya çıkan değişiklikler nedeniyle, kendisi istediği gibi yararlı ömrü, amortisman oranını ve amortisman yöntemini değiştirebilmektedir. Oysa, Türk vergi mevzuatında, böyle bir serbesti olmayıp, VUK' un 339 Seri No.lu Genel Tebliği’ ne göre, Bakanlıkça söz konusu listelerde belirlenen amortisman oran ve sürelerinin dışına çıkılması mümkün değildir (Akyol, 2005: 8).

TMS 16'ya göre maddi duran varlıkların kalan faydalı ömürleri ve buna bağlı olarak seçilen amortisman oranlarının gerçekçiliği her dönem test edilmelidir. Sonraki dönemlerde yapılan değer artırıcı harcamalar, bakım ve tamir gibi uygulamaların düzenli bir biçimde yapılması varlığın faydalı ömrünü uzatırken, teknolojide veya ürünün piyasasında meydana gelen değişimler varlığın faydalı ömrünü kısaltabilir. Bu durumlar göz önüne alındığında varlığın kalan faydalı ömründe ve amortisman oranlarında değişiklik yapılması gerekir ve belirlenen yeni duruma uygun hale getirilir (Örten vd., 2010: 212).

Türkiye muhasebe standartları kapsamında yukarıda belirtilen yöntem ve yaklaşımların uygulanabilirliği örneklendirilmeye çalışılacaktır.

\section{3. “TMS 16", “TMS 8” VE “GERÇEĞE UYGUN DEĞER HIYYERARŞİSI" ÇERÇEVESINDE AMORTISMAN YÖNTEMLERININ UYGULANMASI}

Türkiye muhasebe standartları çerçevesinde amortisman yöntemleri uygulanırken ağırlıklı olarak TMS 16 ve TMS 8 standartları göz önünde bulundurulmaktadır.

TMS 16, Madde 51'e göre; bir varlığın kalıntı değeri ve yararlı ömrü en azından her hesap dönemi sonunda gözden geçirilmeli ve beklentilerin önceki tahminlerden farklı olması durumunda, değişiklik(ler) "TMS 8 Muhasebe Politikaları, Muhasebe Tahminlerindeki Değişikler ve Hatalar" Standardı uyarınca muhasebe tahmininde yapılan değişiklik kapsamında yeniden hesaplanmalıdır.

Çalışmanın bu bölümünde; literatürde yer alan doğrusal amortisman, azalan bakiyeler amortisman ve üretim miktarına göre amortisman yöntemlerine ait uygulanmalar maliyet modeli ve 
yeniden değerleme modeli çerçevesinde örneklendirilmeye çalışılmıştır. Sunulan örnekler; TMS 16, TMS 8 ve gerçeğe uygun değer hiyerarşisi göz önünde bulundurularak detaylandırılmıştır.

\subsection{Maliyet Modeli Uygulaması}

Maliyet bedeli 100.000TL olan bir maddi duran varlık T1 döneminin 8. ayında satın alınarak işletme aktifine alınmıştır. Söz konusu maddi duran varlık 9. aydan itibaren kullanılmaya başlanmıştır. Maddi duran varlığın işletme yönetimince belirlenen faydalı ömrü 5 yıl olup, faydalı ömrün sonundaki kalıntı değerinin 12.700TL ${ }^{3}$ olacağı tahmin edilmektedir. Yıllık faiz oranının \%5 olduğu varsayılacaktır. Maddi duran varlığın 1. Y11 2.500 ton, 2. Yil 3.000 ton, 3. Y1l 3.500 ton, 4. Y1l 4.000 ton ve 5. Y11 2.000 ton olmak üzere, ekonomik ömrü boyunca toplam 15.000 ton üretim gerçekleştirmesi beklenmektedir.

Kalıntı değerin bugünkü değeri $=12.700 /(1+0,05)^{5}=10.000 \mathrm{TL}$

Amortismana tabi tutar $=100.000-10.000=90.000 \mathrm{TL}{ }^{\prime}$ dir .

Örnek gereği T4 döneminde, tahmin edilen kalıntı değerin bugünkü değer hesap sonucu 5.000TL ${ }^{4}$ olarak değiştirilecektir. Yapılan değişik, muhasebe tahminindeki değişiklik niteliğinde olduğundan, yalnızca ileri tarihlerdeki hesaplamalara dahil edilecektir.

\subsubsection{Doğrusal Amortisman Yöntemine Göre Amortisman Uygulaması:}

Y1ll1k Amortisman Tutarı $=90.000 / 5=18.000 \mathrm{TL}$ olacaktır

Maddi duran varlığın aktife alındığı yıl kıst amortisman uygulaması yapılacaktır. Buna göre ilk yıl, söz konusu duran varlığın kullanımına başlandığı 9., 10., 11. ve 12. aylar için amortisman hesaplanacaktır. Kalan aylara isabet eden tutarlar ise müteakip yılın ilgili aylarında amorti edilecektir.

Tablo 3. Doğrusal Amortisman Yöntemine Göre Amortisman Uygulaması

\begin{tabular}{|l|c|c|c|c|}
\hline Yıllar & Amortisman Oranı & Amortisman Tutarı & Birikmiş Amortisman & Net Defter Değeri \\
\hline T1 & $0,20 \times 4 / 12$ & 6.000 & 6.000 & 84.000 \\
\hline T2 & 0,20 & 18.000 & 24.000 & 66.000 \\
\hline T3 & 0,20 & 18.000 & 42.000 & 48.000 \\
\hline T4 & 0,20 & 18.000 & 60.000 & 30.000 \\
\hline T5 & 0,20 & 18.000 & 78.000 & 12.000 \\
\hline T6 & $0,20 \times 8 / 12$ & 12.000 & 90.000 & - \\
\hline
\end{tabular}

Örnek gereği T4 döneminde kalıntı değer tahmini 10.000TL'den 5.000TL'ye düşerse, bu değer ilgili dönemin net defter değerine ilave edilecek ${ }^{5}$ ve bu fark kalan dönemlere ait amortisman tutarlarına, önceden hesaplanan bakiyeleri ile orantılı şekilde dağıtılacaktır.

\footnotetext{
${ }^{3}$ Gerçeğe uygun değer hiyerarşisine göre gerçeğe en uygun değerin 12.700TL olabileceği değerlendirilmiştir.

${ }^{4}$ Gerçeğe uygun değer hiyerarşisine göre kalıntının gerçeğe en uygun değerinde değişme olacağı öngörülmüştür.
} 
T4 döneminde yeniden hesaplanan net defter değeri;

$48.000+5.000=53.000 \mathrm{TL}$ olacaktır ve kalan dönemlerde bu tutar amorti edilecektir .

T4 dönemi amortisman tutarı $=18.000+\frac{18.000}{48.000} \times 5.000=19.875 \mathrm{TL}$

T5 dönemi amortisman tutarı $=18.000+\frac{18.000}{48.000} \times 5.000=19.875 \mathrm{TL}$

T6 dönemi amortisman tutar $1=12.000+\frac{12.000}{48.000} \times 5.000=13.250 \mathrm{TL}$ şeklinde hesaplanacaktır.

Tablo 4. Doğrusal Amortisman Yöntemine Göre Amortisman Uygulaması (Kalıntı değer tahmini değiştirilmiş)

\begin{tabular}{|l|c|c|c|c|}
\hline Yıllar & Amortisman Oranı & Amortisman Tutarı & Birikmiş Amortisman & Net Defter Değeri \\
\hline T1 & $0,20 \times 4 / 12$ & 6.000 & 6.000 & 84.000 \\
\hline T2 & 0,20 & 18.000 & 24.000 & 66.000 \\
\hline T3 & 0,20 & 18.000 & 42.000 & 48.000 \\
\hline T4 & 0,20 & $18.000+1.875$ & 61.875 & 33.125 \\
\hline T5 & 0,20 & $18.000+1.875$ & 81.750 & 13.250 \\
\hline T6 & $0,20 \times 8 / 12$ & $12.000+1.250$ & 95.000 & - \\
\hline
\end{tabular}

\subsubsection{Azalan Bakiyeler Amortisman Yöntemine Göre Amortisman Uygulaması:}

Azalan bakiyeler yönteminde doğrusal amortisman yönteminde kullanılan amortisman oranının iki katı kullanılmaktadır.

Tablo 5. Azalan Bakiyeler Yöntemine Göre Amortisman Uygulaması

\begin{tabular}{|l|c|c|c|c|}
\hline Yıllar & Amortisman Oranı & Amortisman Tutarı & Birikmiş Amortisman & Net Defter Değeri \\
\hline T1 & $0,40 \times 4 / 12$ & 12.000 & 12.000 & 78.000 \\
\hline T2 & 0,40 & 21.600 & 33.600 & 56.400 \\
\hline T3 & 0,40 & 12.960 & 46.560 & 43.440 \\
\hline T4 & 0,40 & 7.856 & 54.416 & 35.584 \\
\hline T5 & Kalan1 & 11.584 & 66.000 & 24.000 \\
\hline T6 & $0,40 \times 8 / 12$ & 24.000 & 90.000 & - \\
\hline
\end{tabular}

T4 döneminde yeniden hesaplanan net defter değeri;

$43.440+5.000=48.440 \mathrm{TL}$ olacaktır ve kalan dönemlerde bu tutar amorti edilecektir.

T4 dönemi amortisman tutarı $=7.856+\frac{7.856}{43.440} \times 5.000=8.760 \mathrm{TL}$

T5 dönemi amortisman tutarı $=11.584+\frac{11.584}{43.440} \times 5.000=12.917 \mathrm{TL}$

\footnotetext{
${ }^{5}$ Kalıntı değer tahmininde bir artış olması durumunda, artış tutarının net defter değerinden düşülmesi gerekmektedir.
} 
T6 dönemi amortisman tutar1 $=24.000+\frac{24.000}{43.440} \times 5.000=26.763 \mathrm{TL}$

Tablo 6. Azalan Bakiyeler Yöntemine Göre Amortisman Uygulaması (Kalıntı değer tahmini değiştirilmiş)

\begin{tabular}{|l|c|c|c|c|}
\hline Yıllar & Amortisman Oranı & Amortisman Tutarı & Birikmiş Amortisman & Net Defter Değeri \\
\hline T1 & $0,40 \times 4 / 12$ & 12.000 & 12.000 & 78.000 \\
\hline T2 & 0,40 & 21.600 & 33.600 & 56.400 \\
\hline T3 & 0,40 & 12.960 & 46.560 & 43.440 \\
\hline T4 & 0,40 & $7.856+904$ & 55.320 & 39.680 \\
\hline T5 & Kalanı & $11.584+1.333$ & 68.237 & 26.763 \\
\hline T6 & $0,40 \times 8 / 12$ & $24.000+2.763$ & 95.000 & - \\
\hline
\end{tabular}

\subsection{3. Üretim Miktarına Göre Amortisman Yöntemi}

Amortisman oran $1=(100.000-10.000) \mathrm{TL} / 15.000$ ton $=6 \mathrm{TL} / \mathrm{ton}$

Tablo 7. Üretim Miktarına Göre Amortisman Yöntemi Uygulaması

\begin{tabular}{|l|c|c|c|c|}
\hline Yıllar & $\begin{array}{l}\text { Amortisman } \\
\text { Hesaplaması }\end{array}$ & $\begin{array}{l}\text { Amortisman } \\
\text { Tutarı }\end{array}$ & $\begin{array}{l}\text { Birikmiş } \\
\text { Amortisman }\end{array}$ & $\begin{array}{l}\text { Net Defter } \\
\text { Değeri }\end{array}$ \\
\hline T1 & $2.500 \times 6 \times 4 / 12$ & 5.000 & 5.000 & 85.000 \\
\hline T2 & $3.000 \times 6$ & 18.000 & 23.000 & 67.000 \\
\hline T3 & $3.500 \times 6$ & 21.000 & 44.000 & 46.000 \\
\hline T4 & $4.000 \times 6$ & 24.000 & 68.000 & 22.000 \\
\hline T5 & $2.000 \times 6$ & 12.000 & 80.000 & 10.000 \\
\hline T6 & $2.500 \times 6 \times 8 / 12$ & 10.000 & 90.000 & - \\
\hline
\end{tabular}

T4 döneminde yeniden hesaplanan net defter değeri;

$46.000+5.000=51.000 \mathrm{TL}$ olacaktır ve kalan dönemlerde bu tutar amorti edilecektir.

$\mathrm{T} 4$ dönemi amortisman tutar $1=24.000+\frac{24.000}{46.000} \times 5.000=26.609 \mathrm{TL}$

T5 dönemi amortisman tutar $1=12.000+\frac{12.000}{46.000} \times 5.000=13.304 \mathrm{TL}$

T6 dönemi amortisman tutar $1=10.000+\frac{10.000}{46.000} \times 5.000=11.087 \mathrm{TL}$

Tablo 8. Üretim Miktarına Göre Amortisman Yöntemi Uygulaması (Kalıntı değer tahmini değiştirilmiş)

\begin{tabular}{|l|c|c|c|c|}
\hline Yıllar & $\begin{array}{l}\text { Amortisman } \\
\text { Hesaplaması }\end{array}$ & $\begin{array}{l}\text { Amortisman } \\
\text { Tutarı }\end{array}$ & $\begin{array}{l}\text { Birikmiş } \\
\text { Amortisman }\end{array}$ & $\begin{array}{l}\text { Net Defter } \\
\text { Değeri }\end{array}$ \\
\hline T1 & $2.500 \times 6 \times 4 / 12$ & 5.000 & 5.000 & 85.000 \\
\hline T2 & $3.000 \times 6$ & 18.000 & 23.000 & 67.000 \\
\hline T3 & $3.500 \times 6$ & 21.000 & 44.000 & 46.000 \\
\hline T4 & $4.000 \times 6$ & $24.000+2.609$ & 70.609 & 24.391 \\
\hline T5 & $2.000 \times 6$ & $12.000+1.304$ & 83.913 & 11.087 \\
\hline T6 & $2.500 \times 6 \times 8 / 12$ & $10.000+1.087$ & 95.000 & - \\
\hline
\end{tabular}




\subsection{Yeniden Değerleme Modeli Uygulaması}

Maliyet modeli uygulama örneğine ilave olarak; T3 döneminde, söz konu maddi duran varlığın gerçeğe uygun değer hiyerarşisine göre yeniden değerlemeye tabi tutulduğu ve değerinde \%10 oranında artış meydana geldiği örneklendirilecektir. Bu değişiklik bir tahmin niteliğinde değildir. Bununla birlikte, söz konusu maddi duran varlığın mukayyet değeri üzerinde değişiklik yapılması gerektiğinden; amortisman tutarı için hem geriye dönük, hem de ileriye dönük hesaplama yapılacaktır.

\%10 artış sonucunda duran varlığın defter değeri 100.000TL'den 110.000TL'ye yükselecektir. 10.000TL değerindeki bu artışla beraber, T1 dönemindeki amortismana tabi değer de 90.000TL'den 100.000TL'ye yükselecektir. Buna göre, amortismana tabi değerdeki oransal artış aşağıdaki gibi hesaplanacaktır:

Amortismana Tabi Değerdeki Oransal Artış: $10.000 / 90.000=\% 11, \overline{1}$

\subsubsection{Doğrusal Amortisman Yöntemine Göre Amortisman Uygulaması:}

T3 döneminde yapılacak yeniden değerleme hesaplaması aşağıdaki gibi olacaktır:

Birikmiş Amortisman Değer Artışı : $24.000 \times \% 11, \overline{1} \cong 2.666,7 \mathrm{TL}$

Tablo 9. Doğrusal Amortisman Yöntemine Göre Amortisman Uygulaması

\begin{tabular}{|l|c|c|c|c|}
\hline Yıllar & Amortisman Oranı & $\begin{array}{l}\text { Amortisman Tutarı } \\
(\% \mathbf{1 1}, \overline{\mathbf{1}}) \text { Arttırılmış }\end{array}$ & $\begin{array}{l}\text { Birikmiş } \\
\text { Amortisman }\end{array}$ & Net Defter Değeri \\
\hline T1 & $0,20 \times 4 / 12$ & $6.000+666,7$ & $6.666,7$ & $93.333,3$ \\
\hline T2 & 0,20 & $18.000+2.000$ & $26.666,7$ & $73.333,3$ \\
\hline T3 & 0,20 & $18.000+2.000$ & $46.666,7$ & $53.333,3$ \\
\hline T4 & 0,20 & $18.000+2.000+1.875$ & $68.541,7$ & $36.458,3$ \\
\hline T5 & 0,20 & $18.000+2.000+1.875$ & $90.416,7$ & $14.583,3$ \\
\hline T6 & $0,20 \times 8 / 12$ & $12.000+1.333,3+1.250$ & 105.000 & - \\
\hline
\end{tabular}

3.2.2. Azalan Bakiyeler Yöntemine Göre Amortisman Uygulaması

T3 döneminde yapılacak yeniden değerleme hesaplaması aşağıdaki gibi olacaktır:

Birikmiş Amortisman Değer Artış1 : $33.600 \times \% 11, \overline{1} \cong 3.733,3 \mathrm{TL}$

Tablo 10. Azalan Bakiyeler Yöntemine Göre Amortisman Uygulaması

\begin{tabular}{|l|c|c|c|c|}
\hline Yıllar & Amortisman Oranı & $\begin{array}{c}\text { Amortisman Tutarı } \\
(\mathbf{\%} \mathbf{1}, \mathbf{1}) \text { Arttırılmış }\end{array}$ & Birikmiş Amortisman & Net Defter Değeri \\
\hline T1 & $0,40 \times 4 / 12$ & $12.000+1.333,3$ & $13.333,3$ & $86.666,7$ \\
\hline T2 & 0,40 & $21.600+2.400$ & $37.333,3$ & $62.666,7$ \\
\hline T3 & 0,40 & $12.960+1.440$ & $51.733,3$ & $48.266,7$ \\
\hline T4 & 0,40 & $7.856+872,9+904$ & $61.366,2$ & $43.633,8$ \\
\hline T5 & Kalanı & $11.584+1.287,1+1.333$ & $75.570,3$ & $29.429,7$ \\
\hline T6 & $0,40 \times 8 / 12$ & $24.000+2.666,7+2.763$ & 105.000 & - \\
\hline
\end{tabular}




\subsection{3. Üretim Miktarına Göre Amortisman Yöntemi}

T3 döneminde yapılacak yeniden değerleme hesaplaması aşağıdaki gibi olacaktır:

Birikmiş Amortisman Değer Artış1 : $23.000 \times \% 11, \overline{1} \cong 2.555,6 \mathrm{TL}$

Tablo 11. Üretim Miktarına Göre Amortisman Yöntemi Uygulaması

\begin{tabular}{|l|c|c|c|c|}
\hline Yıllar & $\begin{array}{l}\text { Amortisman } \\
\text { Hesaplaması }\end{array}$ & $\begin{array}{l}\text { Amortisman Tutarı } \\
(\mathbf{\% 1 1}, \overline{\mathbf{1}}) \text { Arttırılmış }\end{array}$ & $\begin{array}{l}\text { Birikmiş } \\
\text { Amortisman }\end{array}$ & $\begin{array}{l}\text { Net Defter } \\
\text { Değeri }\end{array}$ \\
\hline T1 & $2.500 \times 6 \times 4 / 12$ & $5.000+555,6$ & $5.555,6$ & $94.444,4$ \\
\hline T2 & $3.000 \times 6$ & $18.000+2.000$ & $25.555,6$ & $74.444,4$ \\
\hline T3 & $3.500 \times 6$ & $21.000+2.333,3$ & $48.888,9$ & $51.111,1$ \\
\hline T4 & $4.000 \times 6$ & $24.000+2.666,7+2.609$ & $78.164,6$ & $26.835,4$ \\
\hline T5 & $2.000 \times 6$ & $12.000+1.333,3+1.304$ & $92.801,9$ & $12.198,1$ \\
\hline T6 & $2.500 \times 6 \times 8 / 12$ & $10.000+1.111,1+1.087$ & 105.000 & - \\
\hline
\end{tabular}

\section{SONUÇ}

Türkiye Muhasebe / Finansal Raporlama Standartlarına göre, işletmeler kendileri için en uygun amortisman hesaplama yöntemini tercih ederek, sahip oldukları duran varlıklarını faydası tükendiği ölçüde amorti etmeli, geçerli bir maliyet dağılımı yapmalı ve böylece sermayelerini korumalıdırlar. Ayrıca standartlarda, maddi duran varlıklarının cari değerinde meydana gelen değişmeleri yeniden değerleme modeli yardımı ile finansal raporlarına yansıtmaları gerekliliği de izah edilmektedir. Buna karşın; Vergi Usul Kanunu'nun 269-271. Maddeleri, amortismana tabi iktisadi kıymetlerin işletme aktifine girdikten sonraki süreçte maliyet modeli ile değerlenebileceği; 313-321. Maddeleri, amortisman hesaplamalarının normal amortisman yöntemi, azalan bakiyeler yöntemi ve fevkalade amortisman yöntemi kullanılarak yapılabileceği yönünde bazı kısıtlamalar getirmektedir. Bu sebeplerle; işletmeler, aktiflerini ve sermayelerini koruyabilecek niteliğe sahip amortisman yöntemini seçememekte ve varlıklarının gerçeğe uygun değerinde meydana gelen değişiklikleri finansal raporlarına yansitamamaktadır.

Bu çalışmada; TMS 16 kapsamındaki amortisman yöntemleri, amortismana tabi bir duran varlığın ve bu varlık için tahmin edilen kalıntı değerin gerçeğe uygun değerindeki değişmeler göz önünde bulundurularak örneklendirilmiştir. Sunulan örnek içerisindeki duran varlığın gerçeğe uygun değerindeki değişmeler gerçeğe uygun değer hiyerarşisi çerçevesinde ele alınmış ve bu değişimlerin hesaplama sonuçlarına etkileri yeniden değerleme modeli başlığı altında açıklanmaya çalışılmıştır.

Mevcut vergi yasalarında gerçekleştirilmesi arzu edilen bazı düzenlemeler ile, maddi duran varlıkların faydalı ömürleri içerisindeki değerleri, kalıntı değer tahmini, itfa süresi içerisinde kalıntı değer tahmininde meydana gelebilecek değişiklikler ve varlı̆̆ın brüt defter değerinde meydana gelebilecek değişmeler göz önünde bulundurularak belirlenebilecektir. 
Hesaplamalarda; kullanılacak kalıntı değerde meydana gelen değişiklikler bir tahmin niteliğinde olduğundan; hem cari dönemin amortisman gideri, hem de maddi duran varlığın geriye kalan faydalı ömrü içerisindeki amortisman giderleri değiştirilecek ve böylece, yapılan değişiklikler ilgili dönemin finansal raporlarına yansıtılacaktır. Diğer yandan, yeniden değerlemesi yapılan maddi duran varlığın gerçeğe uygun değerinde meydana gelen değişiklik, geçmişe yönelik yeniden düzenleme gerektiren bir hesaplama yapılması ile finansal raporlara yansıtılacaktır. Örneklerle de izah edilmeye çalışılan bu hesaplamalar ile, aktife kayıtlı bir maddi duran varlığın finansal raporlarda izlenmesi gereken gerçek değeri belirlenmiş olacaktır.

\section{KAYNAKÇA}

Akpınar, A. (2012) "Uluslararas1 Finansal Raporlama Standartlarına Göre Amortismana Tabi Duran Varlıklar ve Türkiye Uygulaması", Gazi Üniversitesi Sosyal Bilimler Enstitüsü, Yayınlanmış Doktora Tezi, Ankara.

Akyol, M. E. (2005) "Dönem Sonu İşlemlerinde Özellik Arz Eden Bazı Hususlar", Vergici ve Muhasebeciyle Diyalog, Aralık, 212: 8-12.

Ayçiçek, F. (2011) "Değeri Düşen Maddi Duran Varlıkların Ölçülmesinde İşletmeye Özgü Değer Olarak Kullanım Değeri", Mali Çözüm, 103: 121-131.

Demir, V. ve Bahadır, O. (2007) “UFRS (TFRS)'deki Değerleme Ölçütleri Kapsamında Şirket Değerlemesinde Defter Değeri Yaklaşımı”, Muhasebe ve Denetime Bakış, 23: 65-79.

Elitaş, C., Akyüz, Y. ve Bulca, H. (2009) "Kıst Amortisman Uygulamasının Uluslararası Finansal Raporlama Standartları ve Türk Muhasebe Sistemi Açısından Karşılaştırılması”, Mali Çözüm Dergisi, 94: 17-32.

Gençoğlu, Ü. G., Özerhan, Y. ve Karabınar, S. (2013) “Türkiye Finansal Raporlama Standartları”, Sakarya: Sakarya Üniversitesi Sürekli Eğitim Araştırma ve Uygulama Merkezi Yayınları.

Gençoğlu, Ü. G. (2010) “Genel Muhasebe”, Bursa: Alfa Aktüel Yayınları.

Lazol, İ. (2004) “Genel Muhasebe”, Bursa: Ekin Kitabevi.

Hatunoğlu, Z. ve Kı1lı, M. (2014) "Tarım İşletmelerinde TMS Çerçevesinde Amortisman Uygulamaları", 2. Uluslararası Muhasebe ve Finans Sempozyumu, 29-31 Mayıs, Bursa.

İpekoğlu, A. ve Tekşan, M. (2008) "Mükelleflerin Faydalı Ömür ve Amortisman Oranı Hususunda Tespit veya İzahat için Maliye Bakanlığına Başvurabilecekleri Durumlar”, Vergi Dünyası Dergisi, 326: 45-49. 
Örten, R., Kaval, H. ve Karapınar, A. (2010) "Türkiye Muhasebe-Finansa Raporlama Standartları Uygulama ve Yorumları", Ankara: Gazi Kitabevi.

Özkan, S. ve Acar, E. E. (2010) "Uluslararası Muhasebe Finansal Raporlama Standartlarının Finansal Tablolar Analizi Üzerindeki Etkilerine Genel Bakış”, Mali Çözüm Dergisi, 97: 49-85.

Pamukçu, F. (2011) “Gerçeğe Uygun Değer Muhasebesi ve Finansal Tablolara Etkisi”, Mali Çözüm Dergisi, 103: 79-95.

Sevilengül, O. (2005) “Genel Muhasebe”, Ankara: Gazi Kitabevi.

Sevilengül, O. (2011) “Genel Muhasebe”, Ankara: Gazi Kitabevi.

Süer, A. Z. ve Şenyiğit, Y. B. (2006) “Amortisman Uygulamasının Ertelenmiş Vergiler Üzerindeki Etkisi ve Finansal Tablolarda Raporlanması” Mali Çözüm Dergisi, 74: 199-213.

Şen, Ç. (2011) "Türkiye Muhasebe Standardı-16 Açısından Maddi Duran Varlıklarda Amortisman Uygulaması", Mali Çözüm Dergisi, 106: 133-159.

Tokay, S. H. ve Deran, A. (2008) "Türkiye Muhasebe ve Finansal Raporlama Standartlari'nda Değerleme Ölçütleri”, Mali Çözüm, 90: 15-47.

Yükçü, S. ve İçerli, Y. (2007) "TMS-16 Maddi Duran Varlıklar Standardına İlişsin Uygulama Önerileri”, Mali Çözüm Dergisi, 82: 15-28.

Finansal Raporlamaya İlişkin Kavramsal Çerçeve

Türkiye Finansal Raporlama Standardı No: 13 - Gerçeğe Uygun Değer Ölçümü.

Türkiye Muhasebe Standard1 No:16 - Maddi Duran Varlıklar.

Vergi Usul Kanunu, 3 Mart 2014 tarih, 435 Sıra No’ lu ve 28961 sayılı Resmi Gazete. 